\title{
The Role of School Counsellor to Handling Student Sexual Harassment Behavior in the School
}

\author{
I Putu Agus Apriliana \\ Universitas Pendidikan Ganesha, Denpasar, Indonesia \\ *Corresponding author, e-mail: agussheback@gmail.com
}

\begin{abstract}
Sexual harassment behavior by students is an international phenomenon. So that, this article presents and describes the role of school counsellor in handling the phenomenon of student's sexual harassment behavior in the school environment. This article is expected to provide knowledge and insight to school counsellor to help student's (client) achieve optimum overall development, especially the result of sexual harassment acts. Sexual harassment behavior can cause (victims) to experience physical and psychological disorders. This pattern of behavior is in the form of verbal, non-verbal and physical. The school counsellor strategy for dealing with this behavior namely collecting information, providing treatment in the form of counseling sevices for victims and choaching for the perpetrators, and conducting evaluation and follow-up. Furthermore, school counsellor strategy to prevent this behavior namely through basic services and create a good relationship with students. Through this article, it is hoped that the understanding of school counsellor on the student's sexual harassment behavior and the handling efforts can be increased, so it will be able to provide maximum service to the students to achieve optimum development.
\end{abstract}

Keywords: Sexual Harassment Behavior, School Counsellor, Student

How to Cite: Apriliana, I. P. A. (2018). The Role of School Counsellor to Handling Student Sexual Harassment Behavior in the School. International Journal of Research in Counseling and Education, 2(1), 6-11. https://doi.org/10.24036/004za0002

\section{Introduction}

Phenomenon of sexual harassment in the school environment has occurred in several countries in the World. In Australia, data from a survey conducted by Australian Human Rights Commission (2016:6) against more than 30,930 people aged 18 years, it is known that 51\% have experienced sexual harassment in the educational environment, where $26 \%$ occurred in college. Furthermore, in the United Kingdom, data from a survey conducted by Girlguiding (2014:8) against more than 1,200 women, it is known that 59\% women and young women aged 13-21 say they have faced some form of sexual harassment at school or college. In the United States, data from a survey conducted by American Association of University Women (2011:30) against more than 1,965 people aged 7-12 years, 33\% said they had experienced sexual harassment in schools such as comments, jokes and attitudes in a sexual context.

In Indonesia, the phenomenon of sexsual harassment in the school environment also occurs in some areas. One case of sexsual harassment that occurs, especially on the province of Bali namely cases of student harassing student in one of high school. Information from the news Bali Express Amlapura (2017), the high school student almost become a victim of suicide result of sexual harassment actions by her classmates. This case begins the joke that doing by male classmates amount four people. They are also say on sexual content to excessive and hold her chest area. This student felt that she had been harassed and reluctant report to the school staff, so she also held it herself. Next, she refuses to hang herself in his room. A few minutes after the incident, his parents saw the condition of the girl is already hanging and weak, until in the end immediately rushed to the hospital and finally the student's lives can be saved.

Seeing the development of sexual harassment behavior by students mentioned above, it can be said that sexual harassment is a serious problem that must get comprehensive handling in school. Wetzel and Brown, (200: 34) suggests that there are several factors that influence sexual harassment behavior in schools namely the experiences of other students who have sexual harassment, school perceptions of sexual harassment 
among students, and the personality of the students themselves. Rinehart and Espelage, (2016:217) explains that school commitments to make prevention efforts on the student sexual harassment have a great influence on other students in the school. For that, creating a school environment that is free from sexual harassment is a very appropriate step to overcome the problem of sexual harassment of students in school.

Basically, each school has its own way of handling sexual harassment problems in school environment. Certainly, must be accordance with school rules. When the issue of sexual harassment occurs in the student, then the school will give punishment to the perpetrator according to the school rules. This process takes place when the sexual harassment act revealed or expressed by the victim (students) to school staff. However, sexual harassment actions that not revealed certainly will not get any treatment, causing the victims worse and make the perpetrators more aggressive.

Handling sexual harassment problems at school, one of which can be done by school counsellor. In this case, school counsellor handles the problem through various BK services such as basic services and responsive services. Of course in this case, the school counsellor is required more sensitive to understand the condition of the development of students. To address the issue, this article will further present and describe the role of school counsellor in addressing the sexual harassment phenomenon of students in the school environment. Of course this article is expected to provide knowledge and insight to the school counsellor in carrying out its duties to help students or client achieve optimum development in their personal, social, learning and career especially as a result of sexual harassment.

\section{Method}

The type of this study is qualitative study in the form of documentation study. In this study, researchers use books, articles, and journals (national and international) as a document to review the variables proposed by researchers. The variables in this study are sexual harassment and the role of school counsellor. Data analysis technique is descriptive qualitative.

\section{Results and Discussion}

\section{Definition of Student Sexual Harassment and Its Impact}

Sexual harassment is define as an act that: 1) is a sexual nature, 2) is not accept 3) denies or limits the ability of students to participate or benefit from a school education program (U.S. Department of Education, 2008:3). Cantrell (2008:16) explains that what is mean by the behavior that is not accepted is certainly a behavior that has a negative impact on students' self-esteem and this behavior is a behavior that violates the rules. Sexual harassment behavior can be regard as a very sensitive behavior especially among students in school (Young and Ashbaker, 2008:14).

From the various opinions mentioned above noted that the sexual harassment behavior of students is a behavior of sexual nature that are not accepted by other students because it will have a negative impact on students who become victims

Students who become victims of sexual harassment in schools will experience physical and psychological disorders. Gruber and Fineran (2007:636) explains that bullying and sexual harassment by students in high school can cause the victim to be inferior, mentally disturbed, physical, traumatized, not spirited, and hurt. AAUW (2001:33-38) explains specifically the impact of sexual harassment on the emotional and behavioral nature of the victims. The emotional impact on the victim's student namely bad, angry, uncomfortable, worried, low self-esteem, dirty, and shocked. Furthermore, the behaviors that will be displayed by students as victims namely it will be alone, not talking much in the classroom, not wanting to go to school, changing seating, staying at home or moving classes, not eating well, having sleep disorders, not paying attention anything, no focus on learning, low learning outcomes, and declining achievement. When viewed on the basic of the sex of the victim, male and female students who become victims of sexual harassment will experience excessive worries and even depression (Bendixen, et al, 2017: 4). In addition to experiencing depression, things that might be done by students as victims of sexual harassment is drinking alcoholic beverages and even using drugs (Rinehart, et al, 2017: 12).

\section{Patterns of Student Sexual Harassment}

In the school environment, the sexual harassment phenomenon usually occurs because students choose to take different actions from other students, in which case the action are based on sexual nature (SHIPS, 1999:2). Sexual harassment actions of students are identical with behaviors that are not accept by other students whose form may be verbal, physical, and other forms (Witkowska, 2005:11). Espelage et al (2016:4) describes such unacceptable forms of behavior as verbal forms of homophobic name calling, comments and sexual rumors, as well as the physical form of making touch, pulling pants, and sexual assault. Strauss (2012:12) also explains that the verbal, nonverbal, or physical nature of sexual harassment has many forms, 
such as commenting, ogling, or touching. To understand more specifically the forms of student sexual harassment behavior in the schools, the authors classify it as follows:

\section{Verbal sexual harassment}

The form of verbal sexual harassment by the students includes 1) Making comments, jokes, movements or gazes on the victim's body 2) Spreading sexual rumors about the victim 3) Saying that the victim likes the same sex namely "lesby" or "gay" 4) Broadcast or praising the victims (AAUW, 2001:2). When students neutralize or accept the verbal sexsual harassment by their friends, it would be difficult to interpret or understand sexual harassment victims verbally, because sexual harassment behavior is unacceptable behavior (Rolfe and Schroeder, 2017:5). So that, this needs to be minimized its existence in school, because the psychological condition of students cannot be know for certain changes.

\section{Physical sexual harassment}

Not all physical contacts of touching or performing common acts are included in the sexual harassment (U.S. Department of Education, 2008:4). The physical form of student sexual harassment includes 1) touching, holding, pinning the victim sexually, 2) deliberately stroking the victim's body sexually 3) Drawing the victim's clothes with sexual intent 4) Pulling the bottom or dropping the victim's clothes 5) Blocking the street of the victim or sexually sacrificing the victim 6) Urging the victim to kiss the perpetrator 7) Urging the victim to do something other than sex than kissing (AAUW, 2001: 2). Of course, this behavior can be observe directly in view of the exact condition without having to perform any procedure.

\section{Other forms of sexual harassment (Non-Verbal)}

The Other form of student sexual harassment behavior includes 1) Show, give, submit pictures, photos, illustrations, messages, or sexual notes to the victims 2) Write messages or sexual strokes about the victim in school equipment and so on 3) Peek at the victim when dressed or look at school (AAUW, 2001: 2). Of course, this form of action can be see with certainty so as not to cause different views on this action.

The forms of sexual harassment of students mentioned above, not only experienced by female students but also male participants become victims. There is no correlation between the social background of students with sexual harassment occurrence in both male and female students (Lee, et al., 1996:383). According to AAUW (2011: 11) explain that female students become victims of sexual harassment as much as $56 \%$ and men as much as $40 \%$. Vega-Gea et al (2015:49-52), on the contrary, the sex of the victim in each of the sexual harassment dimensions of the students, namely: 1 ) The visual or verbal dimension of victimization $53.1 \%$ are female and $63.1 \%$ are male. 2 ) The physical victimization dimension $14.2 \%$ is female and $33.8 \%$ are male. 3 ) $25.7 \%$ visual or verbal aggression dimension experienced aggressively by women and $52.6 \%$ by men 4 ) Aggression physical dimension $5.1 \%$ was experienced aggressively by women and $25.2 \%$ by men. Of the several explanations above, it can see that sexual harassment behavior not only female students, but also male participants become victims.

\section{School Counsellor and Handling of Students Sexual Harassment}

Considering the issue of sexual harassment done by the students to other students bring negative impact, of course this should get serious attention for school especially for school counsellor. Having a duty to facilitate optimum development of students optimally, of course the issue of sexual harassment is part of the task of a school counsellor. Issue of sexual harassment will be difficult to uncover without any report directly to the school counsellor by the victim. In this case, the school counsellor is required to be more sensitive to the development of the students physically and psychologically. For that, professional performance of a school counsellor is need in handling student sexual harassment behavior.

To disclose the problems of the students, the school counsellor can essentially use data collection instrument in the form of test and non-test. Data collection instrument that is through the test will greatly help the school counsellor in understanding the psychological condition of students. Various forms of instruments actually be used, but the weakness of instrument only done at certain periods and total of students are sometimes a constraint in the implementation of tests. Because of that, needed a special strategy to know the physical and psychological development of students every day. In this case, student sexual harassment actions can be occurs at any time. Because of that, the authors will present a special strategy that can done by school counsellor in handling student sexual harassment behavior in the schools as follows:

\section{Gathering information}

In addition to seeing from evaluation result of previous BK program, observation data and test results are very important to analysis related to student sexual harassment behavior. Besides, the next process of gathering information can done by intense approach to students through direct or indirect communication (through the media). The school counsellor must actively communicate with students, so that the problem of 
student can be handle immediately. If communication is directly constrained, the school counsellor can facilitate the communication of students through media such as telephone, message, and through internet service. This is important to do, because the victim sexual harassment tends to be close. The victim he thinks, there is no longer meaningful (low self-esteem) and feel the incident does not need to be convey to anyone. The existence of communication continuously can provide information to the school counsellor about sexual harassment behavior.

\section{Treatments}

After the information received by the school counsellor, students who become victims of sexual harassment, then given treatment in the form of counseling services. Some counseling approaches that can be use namely:

\section{a. The Centered Client Counseling Approach}

This counseling approach has tried by Hanifah and Hartati (2016: 42), to treatment the problem of low self-esteem students in SMPN 25 Semarang. The results show that there has been an increase in self-esteem score where the Pre-Test score (48.45\%) and the Post Test score (75.65\%). This suggests that this approach can used to overcome the problem of students' self-esteem especially as result of sexual harassment.

\section{b. The Cognitive Behavioral Counseling Approach}

This counseling approach has tried by Yasin, Dantes and Dharmayanti (2017: 1) to treatment the problem of low self-esteem students in SMA Negeri 4 Singaraja. The results show that CBT counseling is effective to improve students' self-esteem where (thit $>$ ttable : $11,738>1,943$ ). This suggests that this approach is potentially to treatment the problem of students' self-esteem especially as result of sexual harassment.

\section{c. The Logo Counseling Approach}

This counseling approach has tried by Erlangga (2017:17) to reduce the symptoms of post-traumatic stress in children affected by floods and rob. The results show that there is an increase in the meaning of the child's life after given individual counseling of logo approach. This suggests that this approach can used to address the problem of post-traumatic student especially sexual harassment acts.

\section{d. The Rational Emotive Counseling Approach}

This counseling approach has tried by Pratamawati, Dantes, and Lestari (2017:8) to reduce the anxiety of talking to the students in SMA Negeri 2 Singaraja. The results show that this approach is effective for reducing the anxiety of speaking students where (thitung > ttabel: $27,31>5,99$ ). This suggests that this approach has the potential to use in reducing students' anxiety as result of sexual harassment.

Some of the above counseling approaches known to have potential to use in dealing with students who are victims of sexual harassment behavior. School counsellor can choose one of these approaches that perceived in accordance with the ability that is own and in accordance with the condition of the students (counselee). Hopefully, students who become victims of sexual harassment behavior can be optimum selfdevelopment.

The student become perpetrators of sexual harassment, must get coaching in accordance with school rules. In this case, the collaboration between school counsellor with parents and teacher is very important to do. Therefore, proper coaching of the perpetrators will have an impact on other students in performing similar actions.

\section{Evaluation and Follow Up}

After the counseling process to students who become victims of sexual harassment, monitoring of physical and psychological development is still attention. For that, a follow-up process of counseling is very important, so the counselee feel that the incident has not affected his or her life right now. Services that are responsive, of course, will soon be able to help the development of students to a more optimal direction.

\section{Role of School Counsellor in Prevention of Students Sexual Harassment}

School counsellor can prevent sexual harassment behavior in schools through various BK services in the school, one of them is basic services. Providing classical information services, group guidance, orientation, and so on by taking the topic: "sexual harassment phenomenon by students in the school" will provide new understanding to students about sexual harassment. In the implementation of this service also, can be deliver about the school rules and school actions that will be conduct on cases of sexual harassment. Of course, it will make students become more familiar about the behaviors of his friends, especially sexual harassment behavior. 
In addition to providing understanding to students, the most important thing of sexual harassment prevention namely the school counsellor must be open. School counsellors should be a comfortable sharing partner for students for anything. In the end, students will trust school counsellors for the problems they face and believe the school counsellors can follow up on the issues they face. For that, students will always tell the problem to the school counsellors anytime. The relationship between the school counsellors with this student will be able to handle the problems of the student immediately, especially about sexual harassment behavior.

\section{Conclusion}

Based on the above discussion, it can concluded that the student sexual harassment behavior is a form of sexual nature behavior that is not accept by other students considering the negative impacts caused to the victim. These effects include depression, low self-esteem, mental disorders, physical health, trauma, no life spirits, feel hurt, feel bad, angry, uncomfortable, worried, dirty, and shocked. Pattern of sexual harassment behavior include verbal, non-verbal and physical forms. School counsellors strategy to this problem is 1) its handling strategy includes gathering information through previous BK program evaluation, observation data, test result and interview to students. After the information received, school counsellor can perform treatment to victim's sexual harassment through several counseling approach such us 1) Centered Client Counseling approach, 2) Cognitive Behavioral Counseling, 3) Logo Counseling and 4) Rational Emotive Counseling. The student become perpetrators of sexual harassment, must get coaching in accordance with school rules and working mechanisms school counsellors. Finally, doing of evaluation and follow-up process. 2) Prevention strategies include basic services in the form of classical information services, group guidance, orientation, and so on by taking the topic: "sexual harassment phenomenon by students in the school". In addition, the school counsellor must be open. The role of school counsellors in prevention and handling student sexual harassment behavior is very necessary. The task of school counsellors is to facilitate the optimum development of students in the field of personality, learning, social and career. Through this article, it is hoped that the understanding of school counsellors toward the students' behavior especially on sexual harassment will increase so can be provide the maximum service to the students in the school.

\section{Acknowledgment}

Thanks to my parents who have supported and encouraged, inspired from philosophy lecturers, and all those who have helped provide input in the preparation of this article.

\section{References}

AAUW. 2001. Hostile Hallways, Bullying, Teasing, and Sexual Harassment in School. United States; American Association of University Women Educational Foundation

AAUW. 2011. Crossing the Line, Sexual Harassment at School. United States; American Association of University Women

Australian Human Rights Commission. 2016. University Student Sexual Assault and Sexual Harassment Survey, Notes on Reading Institutional-Level Data. Australia; Australian Human Rights Commission

Bendixen, Mons., Daveronis, Josef., and Kennair, Leif Edward Ottesen. 2017. The Effect of Non-Physical Peer Sexual Harassment on High School Students' Psyschological Well-Being in Norway: Consistent and Stable Finding Across Studies. Int J Public Health. https://doi.org/10.1007/s00038-017-1049-3

Cantrell Jan. 2008. Students Harassing Students, The Emotional and Educational Toll on Kids. United States of America; Rowman \& Littlefield Education

Erlangga, Erwin. 2017. Konseling Logoterapi untuk Mengurangi Gejala Stres Pasca Trauma pada Anak Korban Banjir dan Rob. Philantrophy Journal of Psychology, Vol. 1 No. 1

Esfand, Muthia. 2012. Women Self-Defense, Merdeka dari Rasa Takut. Jakarta; Transmedia Pustaka

Girlguiding. 2014. Girls' Attitudes Survey. London; Girlguiding

Gruber, James E. and Fineran Susan. 2007. The Impact of Bullying and Sexual Harassment on Middle and High School Girls. Journal of Violence Against Women, Volume 13 Number 6. https://doi.org/10.1177/1077801207301557 
Hanifah, Azmi. dan Hartati, Maria Theresia Sri. 2016. Mengatasi Masalah Low Self-Esteem Siswa melalui Konseling Individu Model Person Centered Theraphy. Indonesian Journal of Guidance and Counseling: Theory and Application 5 (3)

Knowledge Networks. 2011. Harassment at School Survey. America; American Associaton of University Women

Lee, Valerie E., Croninger, Robert G., Linn, Eleanor., Chen, Xianglei. 1996. The Culture of Sexual Harassment in Secondary Schools. American Education Research Journal, Vol. 33, No. 2, pp. 383-417. https://doi.org/10.3102/00028312033002383

Pratamawati, Luh., Dantes, I Nyoman.,dan Lestari, Luh Putu Sri. 2017. Efektivitas Konseling Rational Emotif dengan Teknik Assertive Adaptive dan Teknik Bermain Peran untuk Mengurangi Kecemasan Berbicara di Depan Kelas pada Siswa Kelas X SMA Negeri 2 Singaraja. Journal Ilmiah Bimbingan Konseling, Vol. 8 No. 2

Renehart, Sarah J. and Espelage, Dorothy L. 2016. A Multilevel Analysis of School Climate, Homophobic NameCalling, and Sexual Harassment Victimization/Perpetration among Middle School Youth. Journal of Violence, Vol. 6, No. 2, 213-222. http://dx.doi.org/10.1037/a0039095

Renehart, Sarah J., Espelage, Dorothy L., and Bub, Kristen L. 2017. Longitudinal Effects of Gendered Harassment Perpetration and Victimization on Mental Health Outcomes in Adolescence. Journal of Interpersonal Violence 00(0), 1-2. https://doi.org/10.1177/0886260517723746

Rolfe, Shawn M. and Schroeder, Ryan D. 2017. "Sticks and Stones May Break My Bones, but Word Will Never Hurt Me": Verbal Sexual Harassment Among Middle School Students. Article. Journal of Interpersonal Violence 00(0). https://doi.org/10.1177/0886260517709802

SHIPS (Stop Harassment in Public Schools). 1999. Sexual Harassment in School: What Students Suffer and What Schools Should do, A Guide for Student and Their Parents. Texas; Texas Civil Rights Project

Strauss, Susan L. 2012. Sexual Harassment and Bullying. United Kingdom: Rowman\&Littlefield Publishers, Inc.

U.S. Department of Education. 2008. Sexual Harassment, It's Not Academic. America; Office for Civil Rights, U.S. Department of Education

United States Department of Education. 2010. Applicable Regulatory and Policy Standards of Sexual Harassment. America; Office for Civil Rights, U.S. Department of Education

Vega-Gea Esther, Ortega-Ruiz Rosario and Sanchez Virginia. 2015. Peer Sexual Harassment in Adolescence: Dimensions of The Sexual Harassment Survey in Boys and Girls. International Journal of Clinical and Health Psychology

Wetzel, Roberta and Brown, Nina W. 2000. Student-Generated Sexual Harassment in Secondary Schools. London: Bergin \& Garvey

Witkowska, Eva. 2005. Sexual Harassment in Schools: Prevalence, Structure and Perceptions. Sweden: National Institute fo Working Life

Women and Equalities Committee. 2016. Sexual Harassment and Sexual Violence in Schools, Third Report of Session 2016-17. London; House of Commons

Yasin, Ahmad., Dantes I Nyoman., dan Dharmayanti, Putu Ari. 2017. Efektivitas Cognitive Behavioral Therapy (CBT) untuk Meningkatkan Self-Esteem pada Siswa Kelas X.1 BB SMA Negeri 4 Singaraja Tahun Pelajaran 2016/2017. Journal Ilmiah Bmbingan Konseling Undiksha, Vol. 8 No 2

Young, Ellie.L. and Ashbaker, Betty Y. 2008. Addresing Sexual Harassment: Overcoming Sexual Harassment Requires a Combination of Education, Opportunity to Practice Pro-Social Behavior and Disipline. America: National Association of School Psychologist 